\title{
Career and/or Children: Do Female Academic Librarians Pay a Price for Motherhood?
}

\section{Mickey Zemon and Alice Harrison Bahr}

\begin{abstract}
Although women have made significant progress in traditionally maledominated occupations such as law, medicine, business, and science, those who have children are unlikely to advance to the top positions in their fields. This study examines academic librarianship, a "feminized profession" in which women represent close to 70 percent of the work force, to determine if women in the highest-level job, the directorship, have been able to both succeed in their careers and become mothers.
\end{abstract}

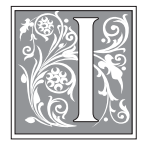

n just a few decades, America has gone from a society in which married women were not expected to work to one in which women anticipate almost a lifetime of paid employment. For all these workplace gains, however, few women who opt to have children can advance to top leadership positions in their professions. For example, in most law and accounting firms, age thirty-four is the average at which promising employees are selected for partnerships. ${ }^{1}$ Although women try to work around the system by delaying marriage and children until they are more secure in their careers, their work environment mitigates against both career and motherhood.

\section{Women in Male-Dominated Professions: Literature Review}

In The Price of Motherhood, Ann Crittenden, an economics journalist who took time out to raise her child, observed the exodus of highly trained women from corporations and leading professional firms because these institutions do not support family responsibilities. ${ }^{2}$ Women without children in business, science, medicine, and other professions are twice as successful in achieving careers than are those with children. ${ }^{3}$ Not only do many drop out of their careers after having children, but the few who stay do so with little paid maternity leave and the expectation that they will work full-time and twice as hard to prove their worth. Those who want to switch to an easier work schedule are relegated to the "mommy track," where prospects for promotion are dim and salaries much less generous.

Crittenden drew on the work of Claudio Goldin, whose 1995 study for the National Bureau of Economic Research traced the demographic and labor force experiences of cohorts of college women

Mickey Zemon is Executive Director of Emerson College Library; e-mail: mickey_zemon@emerson.edu. Alice Harrison Bahr is Dean of Libraries and Instructional Resources at Salisbury University; e-mail: ahbahr@salisbury.edu. The authors acknowledge the assistance of Dr. H. Harry Basehart, Professor of Political Science, Salisbury University, Salisbury, Maryland. 
across the past century. ${ }^{4}$ The first group graduated college between 1900 and 1920 and faced the choice of either a family or a career. The second, graduating between 1920 and 1945, comprised many women who took temporary jobs after college before entering into marriage and family life. Women in the third cohort, graduating between 1946 and 1965, were the first to have the opportunity to have both a family and meaningful employment. The two were to be serially scheduled, however; family first, in terms of timing and priority, then employment. The majority of women in cohorts one and three were teachers, a career that allowed college-educated women to have a family and then enter or reenter a career when their children were older. Graduating college between 1966 and 1979, the women of cohort four were the first to enter the labor force in the era of modern feminism and the first to delay marriage and children while they pursued their careers. Goldin concluded that no cohort of female college graduates had a high success rate in combining family and career. Indeed, even within cohort four, no more than 13 to 17 percent reached midlife with both a career and a family.

Goldin's findings confirm those of Deborah J. Swiss and Judith Walker's 1993 survey of 902 women with graduate degrees from Harvard. ${ }^{5}$ They reported that 25 percent of those who received Harvard MBAs in the 1970s left the workplace entirely by 1990, forced out of the best jobs when they became mothers. Seventy percent cut back their hours after childbirth, many facing resentment when they returned to work because of the time they took off for maternity. The researchers also distinguish three generations of mothers working in male-dominated professions: traditionalists, who started their careers late, after child-rearing; trailblazers, who organized their lives around their profession and sacrificed their family life; and achievers, who carefully planned the timing of their childbearing to fit in with their careers. However carefully they plan, achievers nevertheless face what has come to be known as "the maternal wall": careers blocked by the decision to have children.

In addition to the wall, there is the "glass ceiling": women look up and see what they are capable of achieving, but invisible barriers prevent them from breaking through. Studying women administrators and managers, scientists, lawyers, and accountants from a global perspective, Linda Wirth has shown how few gain the highest positions in their organizations. In the United States, where women are as equally qualified as men and constitute around 46 percent of the workforce, they hold only 5.1 percent of executive positions and represent only 3.3 percent of the highest-paid officers and directors. ${ }^{6}$ Careers in public services do offer women greater opportunity for senior managerial positions but are often restricted to human resources work. Even when women establish their careers before starting families, the interruption of maternity results in losses in seniority, fewer training opportunities, and salary lag.

"More than anything, the meaning and impact of motherhood shadows every woman, narrowing her options," commented Betty Holcomb in discussing the large number of pregnancy discrimination cases in the corporate world. She addressed the negative impact of stereotyping mothers in the workplace, which assumes that they will cut back on their commitment to work, and expressed the need for a critical mass of women in positions powerful enough to counter such assumptions. $^{7}$

Why are so few women in the "best" jobs society has to offer? According to Joan Williams, the problem for women in upper-level management and the professions is not access, but advancement. ${ }^{8}$ Although the gap in education and skills between men and women has closed, the proportional representation of women in high-level white-collar jobs has not increased: only six percent have partnerships in large law firms, five percent in federal elective office, and three percent 
in executive positions at publicly traded corporations. In business and law, the assumption is that women who have children end their commitment to the job. Regardless of how long they delay motherhood, three practices drive them out of the workforce: the grueling executive schedule, the marginalization of part-time work, and their inability to relocate.

Do teaching careers in higher education offer a better option for mothers than those in the corporate world? According to Williams, men still dominate the upper levels of academic posts. Women's rate of tenure, 46 percent, was the same in 1992 as in 1975 , whereas men's tenure rate rose sharply to 72 percent in 1994-1995. ${ }^{9}$ Lynn Hunt has pointed out that the gains female faculty have made are primarily in humanities departments, where salaries tend to be lower, and has suggested that the conflict between tenure requirements and the demands of motherhood may account for the much higher percentage of female-tomale part-time faculty. ${ }^{10}$ A national study analyzing data on how professors with children fare in academe found that women who became mothers within five years of earning a Ph.D. are nearly 30 percent less likely than women without babies to obtain a tenure-track position. The careerbuilding years in higher education are the most likely ones for motherhood; the average age for receiving a doctorate is 33 , and many faculty do not secure tenure under the age of 40 . Only a third of the women in the study who took a university teaching job ever became mothers. ${ }^{11}$

\section{Women in Academic Librarianship}

Like teaching, nursing, and social work, librarianship has long been considered a feminized profession, one that employs a predominately female workforce and is associated with lower salaries and less social prestige. ${ }^{12}$ Although women who entered these professions exercised a new-found independence, they also accepted the sex typing that permitted the creation of jobs appropriate for male workers or female workers, with corresponding different levels of skills, opportunities, responsibilities, and rewards. ${ }^{13}$ The feminized professions have been easily integrated into administrative hierarchies and placed under the authority of male administrators. Until only recently, management has been a male domain and women have not held positions of authority, even in the professions in which they outnumber men.

Do female directors of academic libraries face the same choice-career or children - as the women studied by Crittenden and others? The professions have often been divided into two categories: the traditional, male-dominated domains of law, medicine, university teaching, and the ministry; and the more recent feminized professions, to which librarianship belongs. ${ }^{14}$ Until the last few decades, few women entered the traditional professions, and those who did worked in lower-prestige subspecialties such as pediatrics or real estate law. ${ }^{15}$ Excluded from the existing professions, women participated in developing professions that more closely reflected society's image of feminine roles.

In her 1985 study of sex segregation in academic libraries, Betty Jo Irvine noted that men dominated the executive ranks of academic librarianship until the 1970s. ${ }^{16}$ For a brief time during World War Two, women held higher than their typical percentages of ARL directorships (12.7\% in 1948), but as men returned and reoccupied directorships, the percentage returned to earlier levels (8.7 in 1952). ${ }^{17}$ During the 1970s, however, equal opportunity and affirmative action, along with a new emphasis on participatory management, began to change the power structure of academic libraries. As a result, larger numbers of women had the opportunity to enter the executive ranks in academic libraries. Focusing on women who attained directorships in ARL libraries, Irvine pointed to the family trade-offs they had to make. When these women embarked on their careers, they were more likely to have done so without a spouse or family support system, 
including children. If they did marry and have children, they had fewer than their male counterparts and usually had them prior to assuming administrative careers. She cautioned women contemplating the executive route in ARL libraries that "the prognosis is rather discouraging for combining family and career lives." Looking to the future, she suggested that the trend toward fewer children and two-career couples may reveal "a more propitious pattern for women who seek to combine family and career roles." 18

Although a critical mass of women has attained executive positions in academic libraries since Irvine's study, there has been little subsequent research on how their decision to become mothers has affected their career trajectory. ${ }^{19}$

\section{Methodology}

This study investigates the extent to which female academic library directors have been able to advance their careers and also raise children. This focus does not imply, however, that career versus children is the sole option available to professional women or that not raising children, as a conscious or not conscious decision, is motivated by career alone. Directors were selected not because they are more or less successful than others in their organization but, rather, because they represent a distinct management track that can be analyzed with data available in the literature. The study is quantitative, not qualitative; in other words, no attempt is made to determine how well the directors managed their libraries or raised their children.

Information regarding the gender composition of academic librarians and library directors is available through several sources. The ALA Survey of Librarian Salaries 1998 stated that 68 percent of academic librarians are female. ${ }^{20}$ The same survey in 1999, which included an additional question about gender of directors, indicated that 57 percent of academic library directors are female. ${ }^{21}$ According to Deborah M. Kolb and Ann C. Schaff- ner (2001), 63 percent of librarians in the nation's largest academic and research libraries are women. ${ }^{22}$ The Association of Research Libraries reports that women moved from leading 15.5 to 45.9 percent of the largest libraries between 1980 and $2000 .^{23}$ From these studies, we estimate that women represent between 60 and 70 percent of academic librarians and between almost 50 to almost 60 percent of academic library directors.

To gather information on women directors of academic libraries, a Web survey was designed, pretested, linked to a Microsoft Access database, and results exported to SPSS for analysis. (See appendix A.) The source for identifying participants was an ALA electronic file of mail labels for members who listed themselves as directors and who were affiliated with one of three sections of the Association of College and Universities Libraries Division: University Libraries Section, College Libraries Section, and Community and Junior College Libraries Section. There were 1,049 listings, 377 for men and 483 for women. The remaining 189 listings were eliminated because they were for directors of branch libraries, interim directors, or individuals with the word "director" in their titles who were not academic library directors. ${ }^{24}$

The survey was sent to 539 female academic library directors, the 483 in the ALA file, augmented by 80 additional names forwarded by participants, 24 of whom were subsequently removed because respondents indicated that they had retired or were no longer directors. Of the 539 surveys sent, 349 were returned for a 65 percent response rate, and 347 were usable, that is, they were completed by deans and/or directors.

To distribute the survey electronically, e-mail addresses had to be located for each recipient. This was accomplished by checking the Web sites of the institutions at which they were employed. Surveys were sent twice, once in August, then again to all participants in October, 2003, reminding those who had not already done so to respond. 
Some items in the survey were included for validating data or for ensuring confidentiality. For instance, a question about position title ensured that respondents were exclusively library directors. There were no questions requesting respondent names, the names of their institutions, or marital status. The majority of questions were based on key findings from prior studies that identified principal factors affecting women's career advancement. These included the importance of fulltime work histories, internal promotion, advanced degrees, and the greater likelihood of advancement in smaller and private schools. ${ }^{25}$ Respondents could make general comments and more extensive comments if they indicated that motherhood had had no effect on their careers.

\section{Findings}

Sixty-three percent of respondents had children. Only 37 percent, or 128 of the 347 respondents, did not. Of the 219 with children, 111 had two, 56 had one, 34 had three, and 18 had four or more. Although this suggests that it is possible to make career advancements and have children, it introduces a set of additional questions. Did factors in these female directors' workplaces, careers, and/or personal lives influence the choices they made? the proportion of women raising and not raising children is comparable across all Carnegie classifications. Women with children are no less likely to work at larger schools than are women without them.

These results are also true for FTE and institutional type. For example, 17.2 percent without children and 17.8 percent with children were in schools of fewer than 1,000; 36.7 percent without children and 33.3 percent with children were in schools of 2,500 to 5,000; and 14.1 percent without children and 15.1 percent with children were in schools of between 5,000 and 10,000. Respondents were divided equally between public and private schools, 170 in private and 177 in public. Of those in private schools, 57 out of 128 $(44.5 \%)$ had no children and 113 out of 219 $(51.6 \%) \mathrm{did}$. The numbers were similar for public institutions: 71 out of 128 , or 55.5 percent, had no children, compared to 106 out of 219 , or 48.4 percent, who did.

\section{Career Patterns: Considerations}

Career patterns, as well as institutional, factors were examined. These included years in the current directorship, number of previous directorships, advanced degrees, whether directorships came before, during, or after raising children, and if internal promotion played a significant

\section{Institutional Characteristics: Considerations}

Workplace or institutional characteristics were examined more closely in relationship to the number of children. Included were Carnegie classification, full-time enrollment (FTE), and also institutional character (i.e., private versus public). Earlier studies linked increased opportunity for advancement to small, private institutions. This investigation uncovered no meaningful differences for this or for other institutional characteristics. As table 1 indicates,

\begin{tabular}{|l|c|c|c|}
\hline \multicolumn{4}{|c|}{ TABLE 1 } \\
\hline Children and Carnegie Classification \\
\hline \hline Carnegie Category & $\begin{array}{c}\text { No } \\
\text { Children }\end{array}$ & $\begin{array}{c}\text { At Least } \\
\text { One Child }\end{array}$ & Total \\
\hline Associate categories & 27 & 46 & 73 \\
& $21.1 \%$ & $21 \%$ & $21 \%$ \\
\hline Baccalaureate & 37 & 60 & 97 \\
categories & $28.9 \%$ & $27.4 \%$ & $28 \%$ \\
\hline Master's categories & 29 & 63 & 92 \\
& $22.7 \%$ & $28.8 \%$ & $26.5 \%$ \\
\hline Doctoral categories & 30 & 40 & 70 \\
& $23.4 \%$ & $18.3 \%$ & $20.2 \%$ \\
\hline Not answered & 5 & 10 & 15 \\
& $3.9 \%$ & $4.6 \%$ & $4.3 \%$ \\
\hline Total & 128 & 219 & 347 \\
& $100 \%$ & $100 \%$ & $100 \%$ \\
\hline
\end{tabular}




\begin{tabular}{|l|c|c|c|}
\hline \multicolumn{4}{|c|}{ TABLE 2 } \\
Children and Degrees Earned \\
\hline \hline Degree & $\begin{array}{c}\text { No } \\
\text { Children }\end{array}$ & $\begin{array}{c}\text { At Least } \\
\text { One Child }\end{array}$ & Total \\
\hline MLS/MLIS & 70 & 131 & 201 \\
& $54.7 \%$ & $59.8 \%$ & $57.9 \%$ \\
\hline 2nd & 37 & 49 & 86 \\
Master's & $28.9 \%$ & $22.4 \%$ & $24.8 \%$ \\
\hline 3rd & 1 & & 1 \\
Master's & $.8 \%$ & & $.3 \%$ \\
\hline Ph.D. & 20 & 39 & 59 \\
& $15.6 \%$ & $17.8 \%$ & $17 \%$ \\
\hline Total & 128 & 219 & 347 \\
& $100 \%$ & $100 \%$ & $100 \%$ \\
\hline
\end{tabular}

three or more children in a first directorship (table 3). This finding lends support to a 1993 study of sixty-nine community college directors: "almost three times as many males as females reported three children." 26

Only one of the five career patterns shows a significant difference: internal promotion. This is true for all data compressions. As with number of prior directorships, the most striking instance occurs when number of children is collapsed into three categories: $0-1,2$, and 3+ children. Those data are significant at the $\mathrm{p}=$ .005 level in a chi-square test and in-

role. Again, past studies indicated that women with children tend to be in directorships longer, have fewer directorships, attain fewer degrees, raise their children either before of after becoming directors, and rely on internal promotion for career advancement.

Once again, the data do not support the expectations. There is remarkable comparability between directors with and without children in terms of degrees attained (table 2) and years in position. This is also true for when children were raised: 49 percent raised children before or after advancing to their directorships, and 51 percent during their directorships.

Motherhood does not generally affect the number of prior directorships held by the respondents. Eightythree of the 128 respondents with no children, or 64.5 percent, were in a first directorship. Comparatively, 144 of the $219(65.8 \%)$ of those with children were also in a first directorship. When data on number of children are collapsed into three categories $(0-1,2$, and $3+)$, there is a noteworthy percentage difference in the number of those with

\begin{tabular}{|l|c|c|c|c|}
\hline \multicolumn{5}{|c|}{ TABLE 3 } \\
\hline $\begin{array}{c}\text { Children and Prior Directorships } \\
\text { Directorships }\end{array}$ & $\begin{array}{c}\mathbf{0}-\mathbf{1} \\
\text { Children }\end{array}$ & $\begin{array}{c}\mathbf{2} \\
\text { Children }\end{array}$ & $\begin{array}{c}\text { 3+ } \\
\text { Children }\end{array}$ & Total \\
\hline 0 & 116 & 70 & 41 & 227 \\
& $63 \%$ & 63.15 & $78.8 \%$ & $65.4 \%$ \\
\hline 1 & 50 & 24 & 4 & 78 \\
& $27.2 \%$ & $21.6 \%$ & $7.7 \%$ & $22.5 \%$ \\
\hline 2 & 11 & 13 & 4 & 28 \\
& $6 \%$ & $11.7 \%$ & $7.7 \%$ & $8.1 \%$ \\
\hline $3+$ & 7 & 4 & 3 & 14 \\
& $3.8 \%$ & $3.6 \%$ & $5.8 \%$ & $4 \%$ \\
\hline Total & 184 & 111 & 52 & 347 \\
\hline
\end{tabular}
dicate a weak, but approaching moderate, level of association in a Cramer's V test, V $=.175$ (table 4 ). This is compelling, given past studies. For example, in 1983, Barbara A. Moran noted that "For the females in this study, the only constant in becoming a director was to stay in the institution where they had been an assistant or associate library director." ${ }^{27}$ A few years earlier, Paul Metz also had determined that "The greater propensity of women to be hired from the inside exists in both public and private institutions." ${ }^{28}$ Janet L. Justis's 1993 study both reinforced those findings and suggested a subtle change. More women than men will still promoted internally, but the percentages were slight, 58.14 for women and 46.15 for men. ${ }^{29}$ 


\begin{tabular}{|l|c|c|c|c|}
\hline \multicolumn{5}{|c|}{ TABLE 4 } \\
Children and Internal Promotion \\
\hline \hline $\begin{array}{c}\text { Internal } \\
\text { Promotion }\end{array}$ & $\begin{array}{c}\mathbf{0 - 1} \\
\text { Children }\end{array}$ & $\begin{array}{c}\mathbf{2} \\
\text { Children }\end{array}$ & $\begin{array}{c}\mathbf{3 +} \\
\text { Children }\end{array}$ & Total \\
\hline No & 132 & 65 & 26 & 223 \\
& $71.7 \%$ & $58.6 \%$ & $50 \%$ & $64.3 \%$ \\
\hline Yes & 52 & 46 & 26 & 124 \\
& $28.3 \%$ & $41.4 \%$ & $50 \%$ & 35.75 \\
\hline Total & 184 & 111 & 52 & 347 \\
\hline
\end{tabular}

say motherhood did not influence their advancement. As table 5 indicates, the majority thought they had successfully attained their career goals.

What conditions were responsible for this? Benefits such as maternity leave, paid or otherwise, were not factors; only 66 respondents

This survey does not confirm those earlier findings. Respondents with either no or one child are more likely to be hired from outside than to be promoted from within, by an almost 70/30 ratio. For women with two children, the ratio is closer to $60 / 40$, and for those with three or more children, there is an equal chance of advancing through an external hire or an internal promotion. Although external hires are more likely for either, those with no or one child or those with two, there is still a noteworthy percentage difference regarding external hires: 71.7 percent for those with no child or one child, compared to 58.6 percent for those with two children. Overall, however, data affirm Karen A. Hatcher's 1997 discovery of "a change in the administrative accession path for non-ARL libraries. Women are finding it easier to apply for and obtain library director positions through external hires." ${ }^{\prime 30}$

\section{Balancing Motherhood and Career: Con- siderations}

Several questions were asked of those who had raised children and advanced to the directorship to determine how they had managed to do both and how satisfied they were with their careers. Did they think that motherhood affected their careers, and if so, how? To what did they attribute their success? Did they reach the career goals they had set for themselves?

Of the 219 directors with children, 142 , or 64.8 percent,

\begin{tabular}{|l|c|c|c|}
\hline \multicolumn{4}{|c|}{ TABLE 5 } \\
Children and Satisfaction Reaching \\
Career Goals \\
\hline \hline \multicolumn{1}{|c|}{$\begin{array}{c}\text { Degree of } \\
\text { Satisfaction }\end{array}$} & $\begin{array}{c}\text { No } \\
\text { Children }\end{array}$ & $\begin{array}{c}\text { At Least } \\
\text { One Child }\end{array}$ & Total \\
\hline Unsatisfied/ & 12 & 26 & 38 \\
somewhat satisfied & $9.4 \%$ & $11.9 \%$ & $11 \%$ \\
\hline Satisfied & 21 & 29 & 50 \\
& $16.4 \%$ & $13.2 \%$ & $14.4 \%$ \\
\hline Very satisfied/ & 95 & 164 & 259 \\
totally satisfied & $74.2 \%$ & $74.9 \%$ & $74.6 \%$ \\
\hline Total & 128 & 219 & 347 \\
& $100 \%$ & $100 \%$ & $100 \%$ \\
\hline
\end{tabular}
of those, only 56 reported taking leave. When women directors with children were asked how they were able to handle both career and motherhood, 144 cited a helpful partner, 44 other factors, 25 family support, and seven live-in child care. The importance of a helpful partner is key and has been validated in other fields. For instance, Elliott Parker found that a common thread among women in senior public relations positions who had maintained their full-time careers while having children was a supportive spouse. ${ }^{31}$

Live-in child care received so few responses that it was eliminated. When the remaining factors were cross-tabbed with responses about satisfaction in reaching career goals, the results (table 6) were both statistically significant and substantively significant ( $\mathrm{p}=.027, \mathrm{~V}=.183$ ).

In a more detailed breakdown, the most significant factor for those totally satisfied with career goals was a helpful 


\begin{tabular}{|l|c|c|c|c|}
\hline \multicolumn{5}{|c|}{ TABLE 6 } \\
Factors Affecting Satisfaction Reaching Career \\
Goals \\
\hline \hline \multicolumn{1}{|c|}{$\begin{array}{c}\text { Degree of } \\
\text { Satisfaction }\end{array}$} & $\begin{array}{c}\text { Helpful } \\
\text { Partner }\end{array}$ & Family & Other & Total \\
\hline $\begin{array}{l}\text { Unsatisfied/ } \\
\text { somewhat satisfied }\end{array}$ & 13 & 3 & 71 & 23 \\
\hline Satisfied & 19 & $12 \%$ & $5.9 \%$ & $10.8 \%$ \\
\hline Very satisfied & 49 & 6 & 4 & 29 \\
& $34 \%$ & $52 \%$ & $47.7 \%$ & $39 \%$ \\
\hline Totally satisfied & 63 & 3 & 12 & 78 \\
& $43.8 \%$ & $12 \%$ & $27.3 \%$ & $36.6 \%$ \\
\hline Total & 144 & 25 & 44 & 213 \\
& $100 \%$ & $100 \%$ & $100 \%$ & $100 \%$ \\
\hline
\end{tabular}

affected their careers. Most important to note is that only 77 of 219 , or 35 percent, reported that motherhood affected career advancement.

\section{Conclusion}

For a new group of young women considering academic librarianship, there are immense benefits to joining a profession in which so many women are in top leadership positions. Not only do females now hold the majority of library di-

partner. For those who were very satisfied, the significant factors were family (as distinct from helpful partner) and other. Cited in the "other" category were flex time, women directors as role models, church, daycare, friends, and setting a professional record of accomplishment early in a directorship. As one respondent commented about the difficulty of balancing motherhood and career, "It is possible to have both a career and family. It is difficult to always have them balanced. Sometimes being the director made it easier to take time for family events, and sometimes being the director meant giving up family events for the job."

The study found an interesting relationship between satisfaction in reaching career goals and the effect of motherhood on career advancement $(\mathrm{p}=.000, \mathrm{~V}=$ .364). A much greater percentage of those unsatisfied with attaining their goals reported that motherhood had affected their careers (table 7). Of those totally satisfied in reaching their goals, however, the reverse was true: a much lower percentage reported that motherhood rectorships, but, in some cases, their economic compensation exceeds that of their male counterparts. At the 124 ARL institutions, 52.1 percent of directors are women. ${ }^{32}$ Moreover, as Marta Mestrovic Deyrup points out, academic library directors function rather like CEOs in corporations or of large, nonprofit organizations. They are "responsible for a host of client-centered services that are driven by technology - just as in the private sector. They administer budgets, meet a payroll, supervise building construction and maintenance." 33

\begin{tabular}{|l|c|c|c|}
\hline \multicolumn{4}{|c|}{ TABLE 7 } \\
$\begin{array}{c}\text { Affect of Motherhood on Career and } \\
\text { Satisfaction Reaching Career Goals }\end{array}$ \\
\hline \hline \multicolumn{1}{|c|}{$\begin{array}{c}\text { Degree of } \\
\text { Satisfaction }\end{array}$} & $\begin{array}{c}\text { Affect: } \\
\text { No }\end{array}$ & $\begin{array}{c}\text { Affect: } \\
\text { Yes }\end{array}$ & Total \\
\hline $\begin{array}{l}\text { Unsatisfied/ } \\
\text { somewhat } \\
\text { satisfied }\end{array}$ & 5 & 21 & 26 \\
\hline Satisfied & $3.5 \%$ & $27.3 \%$ & $11.9 \%$ \\
& 19 & 10 & 29 \\
\hline Very satisfied & 58 & 28 & $13.2 \%$ \\
\hline & $40.8 \%$ & $36.4 \%$ & $39.3 \%$ \\
\hline Totally & 60 & 18 & 78 \\
satisfied & $42.3 \%$ & $23.4 \%$ & $35.6 \%$ \\
\hline Total & 142 & 77 & 219 \\
& $100 \%$ & $100 \%$ & $100 \%$ \\
\hline
\end{tabular}


As a profession facing an exodus of leadership through retirements, the results of the survey suggest a clear, competitive edge in attracting the next generation of leaders. ${ }^{34}$ Future research may or may not confirm these findings for directors in special, public, or school libraries. ${ }^{35}$ For the population in this study, however, career advancement was possible without the price of motherhood. Although this does not imply that raising children and maintaining a successful full-time career is easy, it does indicate that, for those who want both, the choice is possible in many academic libraries and that the majority who make the choice are satisfied with the outcome.

\section{Notes}

1. Elizabeth Perle McKenna, When Work Doesn't Work Anymore: Women, Work and Identity (New York: Delacorte Pr., 1997), 83.

2 Ann Crittenden, The Price of Motherhood (New York: Henry Holt, 2001), 28-35.

3. Ibid., 32, 35-44.

4. Claudia Goldin, Career and Family: College Women Look to the Past, Working Paper No. 5188 (Cambridge, Mass.: National Bureau of Economic Research, 1995). 6-7.

5. Deborah J. Swiss and Judith Walker, Women and Work/Family Dilemma: How Today's Professional Women Are Finding Solutions (New York: John Wiley \& Sons, 1993), 49-51.

6. Linda Wirth, Breaking through the Glass Ceiling: Women in Management (Geneva: International Labour Office, 2001), 38-44.

7. Betty Holcomb, Not Guilty: The Good News about Working Mothers (New York: Scribner, 1998), 133-34.

8. Joan Williams, Unbending Gender: Why Family and Work Conflict and What to Do about It (New York: Oxford University Pr., 2000), 67-76.

9. Ibid., 68 .

10. Lynn Hunt, "Has the Battle Been Won? The Feminization of History," Perspectives Online (May 1998): 3.

11. Wilson, Robin, "How Babies Alter Careers for Academics," Chronicle of Higher Education (Dec. 5, 2003): Section A 6-7.

12. Carolyn Basten, "A Feminised Profession: Women in the Teaching Profession," Educational Studies 23, no. 1 (Apr. 1997): 55.

13. Linda R. Silver, "Deference to Authority in the Feminized Professions," School Library Journal (Jan. 1988): 24.

14. Ibid., 25.

15. Ibid.

16. Betty Jo Irvine, Sex Segregation in Librarianship: Demographic and Career Patterns of Academic Library Administrators, Contributions in Librarianship and Information Science Number 53 (Westport, Conn.: Greenwood Pr., 1985), Preface.

17. James G. Neal, Turnover Trends: Directors of ARL Libraries 1948-2002, Oct. 16, 2002. PowerPoint presentation of ARL presentation available online at http://www.arl.org/arl/proceedings/141/neal_files/frame.htm].

18. Irvine, Sex Segregation in Librarianship, 144.

19. Numerous studies point to the rise of women in executive library positions. Deborah Hollis's 1999 study of the eighty-six academic libraries in larger, well-known Division I National Collegiate Athletic Association institutions indicates a 25 percent increase in the number of women academic deans, rising from 18 percent in 1986 to 43 percent in 1997 (67). Deborah R. Hollis, "Affirmative Action or Increased Competition: A Look at Women and Minority Library Deans," Journal of Library Administration 27, no. 1/2 (1999): 49-75. In Janet Justis's 1993 study of the top administrators in Virginia and North Carolina community and junior colleges, 62 percent of directors were female and 38 percent male: Janet L. Justis, "An Examination of Career Development Patterns of Administrators of Junior and Community College Libraries/Learning Resource Centers in North Carolina and Virginia" (Thesis, Chapel Hill, University of North Carolina, 1993), 20. Wilder's 2003 ARL report indicates that since 1997, 50 percent of the available directorships have been filled by women: Stanley J. Wilder, Demographic Change in Academic Librarianship (Washington, D.C.: Association of Research Libraries, 2003), 47.

20. Mary Jo Lynch, "Librarians' Salaries: Smaller Increases This Year," American Libraries 29, no. 10 (Nov. 1998): 68. 
21. - Library Directors: Gender and Salary (1999). ALA Human Resource Development and Recruitment. Available online at http://www.ala.org/hrdr/1000_report.html.

22. Deborah M. Kolb and Ann C. Schaffner, "Negotiating What You're Worth," Library Journal 126, no. 17 (Oct. 15, 2001): 52.

23. Wilder, Demographic Change in Academic Librarianship.

24. This percentage of 44 percent male and 56 percent female directors is close to the 50 to 60 percent range indicated by earlier studies. It also mimics closely data in the 2001-2002 American Library Directory, which lists 1,132 academic libraries after excluding departmental, law, medical, and religious libraries from the total of 3,406 academic libraries. Presuming at least 56 percent of those institutions had female directors, the population would be 634 .

25. In Sex Segregation in Librarianship (p. 13), Irvine referenced a point that Eli Ginzberg made in his 1966 study (Life Styles of Educated Women, Columbia University Press), "the critical importance of a continuous, full-time work history to a woman's ability to hold an administrative position" and "that the number of children a woman had negatively affected her ability to exhibit an uninterrupted career pattern." In an even earlier study, Amitai Etzioni's The Semi-Professions and Their Organization (New York: Free Press, 1969, 229), the author noted, "That discontinuous careers account in part for woman's failure to advance within their occupations is indicated by the greater success of single than of married women." Irvine also referenced (p.9) Shick's 1950's survey of the chief librarians at larger schools, "Meet the College Librarian," Library Journal 74 (June 15, 1950), in which Shick wrote: "Women apparently have more difficulty in reaching the top position through recruitment from other libraries. Slightly more than half of them were promoted from positions in the same library compared to only $28 \%$ of the men" (p. 1,019). Karen A. Hatcher's "Succession Paths for Academic Library Directors," Journal of Library Administration 24, 3 (1997): 31-47, covered earlier studies validating the critical importance of internal promotion to academic female librarians' career advancement and the greater likelihood of women rising to top positions at smaller, private institutions. Shick's 1950s survey of the chief librarians at larger schools reported that there were no women in charge of schools with more than 10,000 students. W. C. Blankenship reached a similar conclusion in his 1967 survey of 414 institutions with enrollments under 5,000: Men were more likely to be at the lead of both public and larger libraries: W. C. Blankenship, "Head Librarians: How Many Men? How Many Women? College \& Research Libraries (Jan. 1967): 47. Even in "Career Patterns of Academic Library Administrators," College and Research Libraries 44, no. 5 (Sept. 1983): 337, Barbara A. Moran concluded that "The heaviest concentration of females as directors of libraries was in private institutions." Irvine (p. 9) and Schick address, if not the relationship between degrees and advancement, then the noticeable absence of advanced degrees when men and women are compared.

26 . In the course of this study, the $0-1,2$, and $3+$ compressions, although yielding no statistically significant differences, occasionally pointed to interesting findings: little differences between those with no children and those with one child and, as in this case, some differences beginning with three children. Justis, "An Examination of Career Development Patterns of Administrators of Junior and Community College Libraries/Learning Resource Centers in North Carolina and Virginia," 24.

27. Moran, "Career Patterns of Academic Library Administrators," 343.

28. Paul Metz, "Administrative Succession in the Academic Library," College and Research Libraries 44, no. 5 (Sept. 1978): 362

29. Justis, "An Examination of Career Development Patterns of Administrators of Junior and Community College Libraries/Learning Resource Centers in North Carolina and Virginia," 33.

30. Karen A. Hatcher, "Succession Paths for Academic Library Directors," Journal of Library Administration 24, no. 3 (1997): 42.

31. Elliott Parker, "Women in PR Careers," conference paper, Association for Education in Journalism and Mass Communications (AEJMC) Conference, Chicago, Illinois (September 28, 1997): 9. http://list.msu.edu/cgi-bin/wa?A2-ind9709D\&L=aejmc\&P=R53783.

32. Marta Mestrovic Deyrup, "Is the Revolution Over? Gender, Economic, and Professional Parity in Academic Library Leadership Positions," College \& Research Libraries (May 2004): 242.

33 Ibid., 243

34. William M. Curran, "Succession: The Next Ones at Bat," College \& Research Libraries 64, no. 2 (Mar. 2003): 134.

35. Additional research can focus on areas not covered by this study. For example, the survey avoided questions that were or could be controversial, such as marital status or age, although they are relevant to the study. Similarly, the study limited responses for successfully balancing motherhood and career to family support, live-in child care, helpful partner, and other. As respondents pointed out, many other choices were important. Another finding relevant to future studies is the grouping of number of children into $0-1,2$, and 3 or more. 
APPENDIX A

Career and/or Children?

A Survey of Women Academic Library Directors

1. What is your institution's FTE? Less than 1,000

2. Is it a public or private institution? Public

3. What is its Carnegie classification? (required)

Associate's Colleges -

4. In what state or country is the institution located? (Enter either a two-letter abbreviation for U.S. states or the full name of the country.)

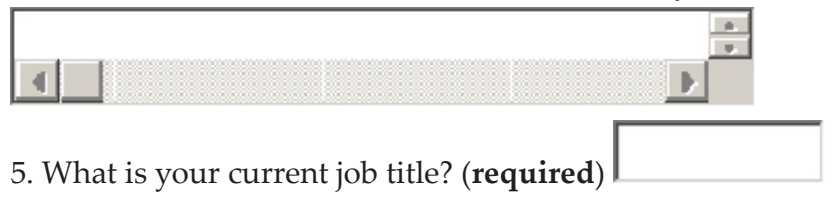

6. How many years have you held your current position? 1 Year or Less

7. Were you promoted to your position from within? No

8. How many prior directorships have you held? 0

9. What is your highest degree? MLS or MLIS

10. How many children do you have? (required) \begin{tabular}{ll|}
${\hline}$
\end{tabular}

If you answered 0 to question 10, skip to question 17.

11. Did you establish your career as a director/dean before, during, or after having and/or raising children? Before $\mathbf{}$

12. On average, how much maternity leave did you take?

Not Applicable

What percent of that leave was paid? Not Applicable

13. How were you able to handle both motherhood and career?

Helpful partner

14. Did motherhood affect your career advancement? $\begin{array}{ll}\text { No } & \boldsymbol{\nabla} \text { (required) }\end{array}$ If you answered No to question 13, skip to question 16.

15. If yes, did it affect your

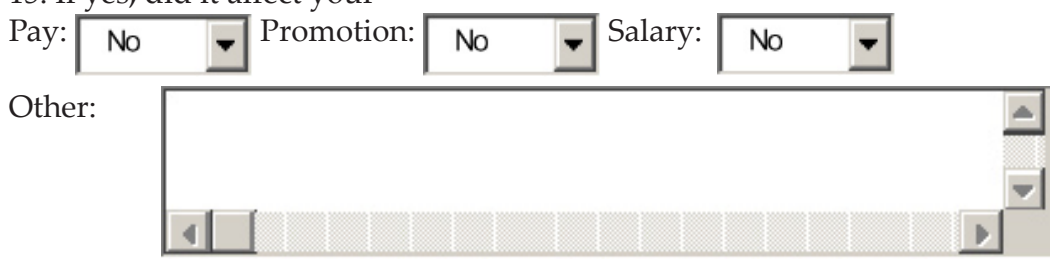


16. If motherhood didn't affect your career, why not?

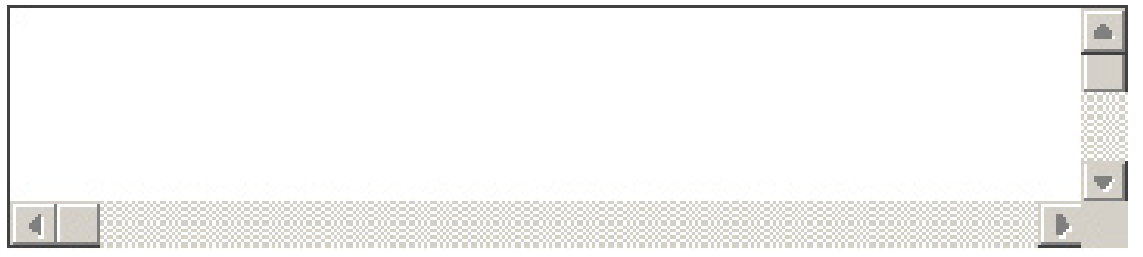

17. Have you achieved the career goals you set for yourself?

Totally Satisfied

18. Use the space below to make any additional comments.

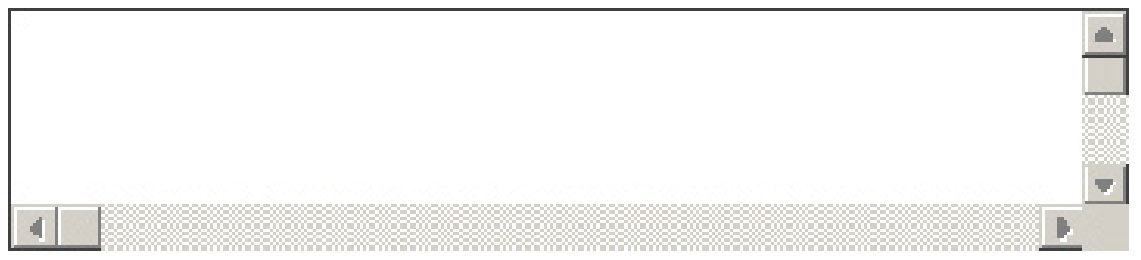

Thank you for taking time to complete this survey.

Reset Submit




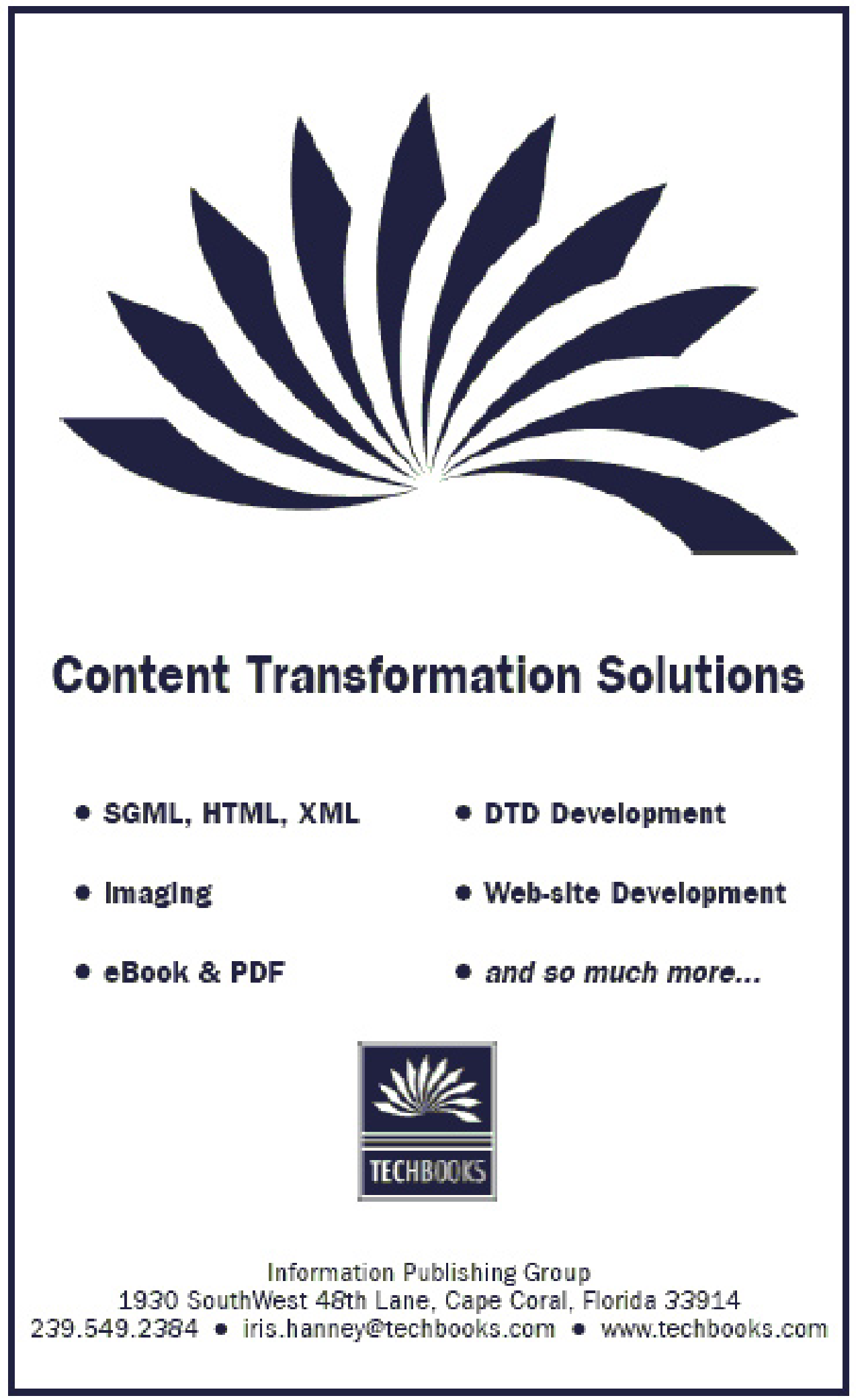

